\title{
First photographic records of the giant manta ray Manta birostris off eastern Australia
}

Lydie I. E. Couturier, Fabrice R. A. Jaine, Tom Kashiwagi

We present the first photographic evidence of the presence of the giant manta ray Manta birostris in east Australian waters. Two individuals were photographed off Montague Island in New South Wales and off the north east coast of Tasmania, during summer 2012 and 2014, respectively. These sightings confirm previous unverified reports on the species occurrence and extend the known distribution range of $\mathrm{M}$. birostris to $40 \circ \mathrm{O}$. We discuss these findings in the context of the species' migratory behaviour, the regional oceanography along the south east Australian coastline and local productivity events. 
1 Lydie I. E. Couturier 1,2, Fabrice R. A. Jaine ${ }^{2,3,4}$ and Tom Kashiwagi ${ }^{1,5}$

$2 \quad{ }^{1}$ School of Biomedical Sciences, The University of Queensland, St Lucia, QLD 4072, Australia

$3 \quad{ }^{2}$ Climate Adaptation Flagship, CSIRO Marine and Atmospheric Research, Dutton Park, QLD

4 4102, Australia

$5 \quad$ Biophysical Oceanography Group, School of Geography, Planning and Environmental

6 Management, The University of Queensland, St. Lucia, QLD 4072, Australia

$7 \quad{ }^{4}$ Marine Megafauna Foundation, Manta Ray \& Whale Shark Research Centre, Tofo Beach,

8 Inhambane, Mozambique

$9 \quad{ }^{5}$ Molecular Fisheries Laboratory, The University of Queensland, St Lucia QLD 4072, Australia

10 Corresponding author: L. I. E. Couturier, School of Biomedical Sciences, The University of

11 Queensland, St Lucia, QLD 4072, Australia, email: lydie.couturier@outlook.com

\section{INTRODUCTION}

13 Manta rays (Manta spp.) are amongst the largest filter-feeding elasmobranch fishes and have a

14 circumglobal distribution through tropical and temperate coastal waters, offshore islands and 15 seamounts (Marshall, Compagno \& Bennett 2009). Manta rays belong to the family Mobulidae,

16 comprising the two genera Manta Bancroft, 1829 and Mobula Rafinesque, 1810. All mobulid

17 species are epipelagic zooplanktivores that are presumed to be long lived (e.g. $>30$ years for

18 Manta spp.) and have low fecundities (i.e. late maturity, long gestation period and only a single

19 large pup (Couturier et al. 2012). Previously considered to be monospecific (Manta birostris), the

20 genus Manta was redescribed in 2009 to comprise two distinct species: the reef manta ray Manta

21 alfredi (Krefft, 1868) and the giant manta ray Manta birostris (Walbaum, 1792), and a third

22 putative species M. cf. birostris (Marshall, Compagno \& Bennett 2009). Both recognised species

23 have circumglobal distributions, sympatric in some areas and allopatric in others (Kashiwagi et

24 al. 2011). Manta birostris is considered a more oceanic and migratory species, and is found

25 predominantly in cooler, temperate to subtropical waters (Marshall et al. 2011). Manta alfredi

26 displays a high degree of site fidelity in tropical and subtropical waters, but may also undertake

27 local to regional-scale ( $>700 \mathrm{~km}$ ) movements and seasonal migrations (Dewar et al. 2008;

28 Couturier et al. 2011; Deakos, Baker \& Bejder 2011; Marshall, Dudgeon \& Bennett 2011;

29 Couturier et al. 2014; Jaine et al. 2014).

30 Both manta ray species and four of the nine described Mobula species are reported to

31 occur in tropical to temperate waters of Australia (Last \& Stevens 2009; Marshall, Compagno \&

32 Bennett 2009). While the occurrence of M. alfredi has been widely confirmed off the coast of

33 eastern Australia (Couturier et al. 2011; Couturier et al. 2014), the occurrence of M. birostris in

34 this region has been lacking photographic validation despite records in literature (Hutchins \& 
35 Swainston 1986; Allen et al. 2006; Last \& Stevens 2009). The recent separation in the genus

36 Manta spp. means that records of M. birostris prior to 2009 lacking photographic evidence cannot

37 be validated, as species may have been confused with $M$. alfredi. This paper presents the first

38 photographic evidence confirming the occurrence of $M$. birostris in east Australian waters, with

39 one specimen photographed off Montague Island, New South Wales, in January 2012 and one

40 specimen photographed off the northeast coast of Tasmania in January 2014.

41 MATERIALS AND METHODS

42 As part of a larger study, photographs of manta rays were sought from dive clubs, dive

43 instructors, researchers and recreational divers along eastern Australia for photographic

44 identification purposes (see Couturier et al. 2011). Four photographs and two video recordings of

45 a free swimming $M$. birostris were taken by Peter McGee, a recreational diver, off Montague

46 Island (36 $15^{\prime} 7.15^{\prime \prime} \mathrm{S} ; 150^{\circ} 13^{\prime} 35.19^{\prime \prime} \mathrm{E}$; Figure 1) offshore from Narooma in southern New South

47 Wales (Specimen \#1, Figure 2a). The individual was sighted near an Australian fur seal

48 Arctocephalus pusillus (Schreber, 1775) colony on the $5^{\text {th }}$ January 2012, swimming at a depth of

49 about $13 \mathrm{~m}$, in $21^{\circ} \mathrm{C}$ waters (P. McGee pers. comm.).

50 One photograph of a free swimming M. birostris was taken from the surface by Leo

51 Miller, a recreational fisherman, off the north east coast of Tasmania $\left(40^{\circ} \mathrm{S} ; 148^{\circ} \mathrm{E}\right.$, no precise

52 location given; Figure 1) on the $26^{\text {th }}$ January 2014. The photograph was submitted to the

53 University of Tasmania Institute of Marine and Antarctic Studies' Redmap website

54 http://www.redmap.org.au/ (Specimen \#2, Figure 2b).

55 Characters used to confirm identification of Manta spp. were terminal mouth, broad head

56 and body coloration. Species identification was based on key morphological features provided by

57 Marshall et al. (2009) including (1) distinct shoulder patches with triangular shape, (2) presence

58 of a caudal spine, (3) distinctive dark spots on the ventral side over abdominal region, with no

59 spots present medially between the gills slits, (4) prominent semi-circular marking extending

60 posteriorly from both $5^{\text {th }}$ gills and (5) dark-coloured margin on posterior edges of pectoral fins.

\section{RESULTS AND DISCUSSION}

62 Key morphological features, including terminal mouth, broad head, distinctive ventral and dorsal

63 coloration, and presence of caudal spine, could be distinguished from photographs of Specimen

$64 \# 1$ (Figure 2a). Together these features allow the specimen to be identified as M. birostris and

65 positively differentiated from M. alfredi, also known to occur in east Australian waters (Couturier 
66 et al. 2011). The distinctive dorsal coloration of Specimen \#2 was the only observable

67 morphological feature identifying this individual as M. birostris (Figure 2b).

68 The occurrence of M. birostris off Montague Island at $\sim 36^{\circ} \mathrm{S}$ in east Australia is consistent

69 with records in south western Pacific Ocean where the species occurs up to $36^{\circ} \mathrm{S}$ (Duffy \&

70 Abbott 2003; Kashiwagi et al. 2011) and in the south western Atlantic where it occurs up to $34^{\circ} \mathrm{S}$

71 (Marshall et al. 2011). Manta ray sightings off Montague Island have been reported in a scuba

72 divers guide (Byron 1986) and in anecdotal reports (N. Coleman \& J. Van Der Westhuizen pers.

73 comm.). Manta rays are also commonly advertised as possible diving encounters during austral

74 summer by most dive operators using this dive site (e.g. Narooma Charters, Islands Charters).

75 These unverified sightings were likely to be of $M$. birostris considering that $M$. alfredi

76 distribution range does not appear to extend beyond $30^{\circ} \mathrm{S}$ worldwide (Marshall, Compagno \&

77 Bennett 2009; Couturier et al. 2014). In addition, M. alfredi was not sighted southward of the

78 South Solitary Island $\left(30^{\circ} 12^{\prime} 24.33^{\prime \prime} \mathrm{S}, 153^{\circ} 16^{\prime} 2.52^{\prime \prime} \mathrm{E}\right)$ in east Australia despite continuous

79 monitoring effort along the coast over the last 5 years (Couturier et al. 2011; Couturier et al.

80 2014).

81 The scarce information available on M. birostris migration ecology shows that its

82 movements are timed with seasonal oceanographic events known to enhance productivity.

83 Seasonal occurrence of the species off south-eastern Brazil was associated with a low salinity

84 coastal front (Luiz et al. 2009), while movements of tagged manta rays in the Gulf of Mexico

85 were linked to seasonal upwelling events and thermal fronts (Graham et al. 2012). Manta

86 birostris and several Mobula spp also occur off North East New Zealand during summer months,

87 which coincide with the path and flow of the East Auckland Current (Duffy \& Abbott 2003).

88 The occurrence of M. birostris off Montague Island may be linked to regional circulation

89 patterns and productive oceanographic events during summer. The East Australian Current (EAC)

90 flows pole-ward along the east Australian coast and its main EAC jet bifurcates abruptly to the

91 east at $32^{\circ} \mathrm{S}$. About a third of the main EAC jet continues south into the Tasman Sea, towards

92 Montague Island, as a series of dynamic eddies (Ridgway \& Godfrey 1997; Roughan et al. 2011).

93 Enhanced nutrient concentrations and upwelling processes have been documented during austral

94 spring and summer south of the separation point where Montague Island is located (e.g. Oke \&

95 Middleton 2001; Roughan \& Middleton 2004; Ridgway 2007). These conditions generate

96 ephemeral but highly productive phytoplankton blooms along the coast (Hallegraeff \& Jeffrey

97 1993; Bax et al. 2001), that likely boost the abundance of zooplankton prey. Humpback whales

98 Megaptera novaeangliae regularly feed on small pelagic fish and coastal krill Nyctiphanes 
99 australia along the southeast Australian coast during their southward migration (Stamation et al.

100 2007). It is probable that M. birostris also occur in this area during warmer months to exploit

101 local productivity events.

102 The occurrence of $M$. birostris off north east Tasmania at $\sim 40^{\circ} \mathrm{S}$ is the newly-extended

103 southern-most record for the species. This sighting may be linked to exceptional oceanographic

104 conditions occurring in the area at the time of the sighting or a response to warming waters by

105 climate-driven change. South-east Australia is a global warming hotspot where the sea surface

106 temperatures have been increasing up to 3 times the global average rate over the past 50 years,

107 and are projected to rise further into the future (Ridgeway \& Hill 2012; Wu et al. 2012; Hobday

108 \& Pecl 2014; Oliver et al. 2014). Southward range extensions have already been reported in this

109 region for plankton communities, macroalgae, macro-invertebrates and fish (Johnson et al. 2011;

110 Last et al. 2011; Ridgeway \& Hill 2012). Sea surface temperatures around the sighting area

111 usually vary between $12^{\circ} \mathrm{C}$ in winter and $17^{\circ} \mathrm{C}$ in summer (Condie \& Dunn 2006). In warm years,

112 temperatures were reported to increase up to $2^{\circ} \mathrm{C}$ above average temperatures recorded 60 years

113 ago due to the circulation change of the EAC (Ridgway 2007; Ridgeway \& Hill 2012). Although

114 M. birostris may tolerate low temperature for short periods of time (e.g. during deep dives), its

115 distribution in tropical and subtropical waters suggest a preference for temperatures above $17^{\circ} \mathrm{C}$

116 (Marshall et al. 2011; Graham et al. 2012). It is possible that at the time of the sighting the EAC

117 flow had extended southward along the Tasmanian coast with increased strength (Ridgeway \&

118 Hill 2012; Oliver \& Holbrook 2014), engendering favourable environmental conditions for $M$.

119 birostris. In addition to providing a suitable thermal habitat, the intrusion of warmer waters along

120 the east Tasmanian coast may trigger productivity events (Matear et al. 2013), providing new

121 food resources for the species. Based on these observations, we confirm the presence of $M$.

122 birostris for the first time in east Australian waters, increasing the known range of the species.

123 The scarcity of recorded observations of $M$. birostris compared to $M$. alfredi, despite vibrant

124 diving and boating activities along the $\sim 4,000 \mathrm{~km}$ east Australian coastline, suggests that the

125 species is rare in the area. It is also possible that the species occupies and traverses areas that are

126 not exploited by fisheries and/or tourism and thus remain undetected.

\section{ACKNOWLEDGEMENTS}


128 The authors wish to thank the two photographers Peter McGee and Leo Miller for contributing

129 photographs, and J. Bruno, R. Graham and S. Prado for their valuable comments on the

130 manuscript.

131

132

133

134

135

136

137

138

139

140

141

142

143

144

145

146

147

148

149

150

151

152

153

154

155

156

157

158

159

160

161

162

163

164

165

166

167

168

169

170

171

\section{REFERENCES}

Allen GR, Cross NJ, Hoese DF, Bray DJ. 2006. Myliobatidae. In: Beesley PL, Wells A, eds. Zoological Catalogue of Australia, Volume 35. Collingwood, VIC, Australia: ABRS \& CSIRO Publishing, 205-209.

Bax NJ, Burford M, Clementson L, Davenport S. 2001. Phytoplankton blooms and production sources on the south-east Australian continental shelf. Marine and Freshwater Research 52:451-462.

Byron T. 1986. Scuba divers guide, southern New South Wales coast Sydney, Australia: Aqua Sports Publication.

Condie SA, Dunn JR. 2006. Seasonal characteristics of the surface mixed layer in the Australasian region: implications for primary production regimes and biogeography. Marine and Freshwater Research 57:569-590.

Couturier LIE, Dudgeon CL, Pollock KH, Jaine FRA, Bennett MB, Townsend KA, Weeks SJ, Richardson AJ. 2014. Population dynamics of the reef manta ray Manta alfredi in eastern Australia. Coral Reefs 33:329-342.

Couturier LIE, Jaine FRA, Townsend KA, Weeks SJ, Richardson AJ, Bennett MB. 2011. Distribution, site affinity and regional movements of the manta ray, Manta alfredi (Krefft, 1868), along the east coast of Australia. Marine and Freshwater Research 62:628-637.

Couturier LIE, Marshall AD, Jaine FRA, Kashiwagi T, Pierce SJ, Townsend KA, Weeks SJ, Bennett MB, Richardson AJ. 2012. Biology, ecology and conservation of the Mobulidae. Journal of Fish Biology 80:1075-1119.

Deakos MH, Baker JD, Bejder L. 2011. Characteristics of a manta ray Manta alfredi population off Maui, Hawaii, and implications for management. Marine Ecology Progress Series 429:245-260.

Dewar H, Mous P, Domeier M, Muljadi A, Pet J, Whitty J. 2008. Movements and site fidelity of the giant manta ray, Manta birostris, in the Komodo Marine Park, Indonesia. Marine Biology 155:121-133.

Duffy CAJ, Abbott D. 2003. Sightings of mobulid rays from northern New Zealand, with confirmation of the occurrence of Manta birostris in New Zealand waters. New Zealand Journal of Marine and Freshwater Research 37:715-721.

Graham RT, Witt MJ, Castellanos DW, Remolina F, Maxwell S, Godley BJ, Hawkes LA. 2012. Satellite tracking of manta rays highlights challenges to their conservation. PloS one 7:e36834.

Hallegraeff G, Jeffrey S. 1993. Annually recurrent diatom blooms in spring along the New South Wales coast of Australia. Marine and Freshwater Research 44:325-334.

Hobday AJ, Pecl GT. 2014. Identification of global marine hotspots: sentinels for change and vanguards for adaptation action. Reviews in Fish Biology and Fisheries 24:415-425.

Hutchins B, Swainston R. 1986. Sea fishes of southern Australia. Perth. Australia: Swainston Publishing.

Jaine FRA, Rohner CA, Weeks SJ, Couturier LIE, Bennett MB, Townsend KA, Richardson AJ. 2014. Movements and habitat use of reef manta rays off eastern Australia: offshore 
172

173

174

175

176

177

178

179

180

181

182

183

184

185

186

187

188

189

190

191

192

193

194

195

196

197

198

199

200

201

202

203

204

205

206

207

208

209

210

211

212

213

214

215

216

217

218

219

220 excursions, deep diving and eddy affinity revealed by satellite telemetry. Marine Ecology Progress Series 510:73-86.

Johnson CR, Banks SC, Barrett NS, Cazassus F, Dunstan PK, Edgar GJ, Frusher SD, Gardner C, Haddon M, Helidoniotis F. 2011. Climate change cascades: Shifts in oceanography, species' ranges and subtidal marine community dynamics in eastern Tasmania. Journal of Experimental Marine Biology and Ecology 400:17-32.

Kashiwagi T, Marshall AD, Bennett MB, Ovenden JR. 2011. Habitat segregation and mosaic sympatry of the two species of manta ray in the Indian and Pacific Oceans: Manta alfredi and M. birostris. Marine Biodiversity Records 4:e53.

Last PR, Stevens JD. 2009. Sharks and rays of Australia. Second edition: CSIRO Publishing.

Last PR, White WT, Gledhill DC, Hobday AJ, Brown R, Edgar GJ, Pecl G. 2011. Long-term shifts in abundance and distribution of a temperate fish fauna: a response to climate change and fishing practices. Global Ecology and Biogeography 20:58-72.

Luiz OJ, Balboni AP, Kodja G, Andrade M, Marum H. 2009. Seasonal occurrences of Manta birostris (Chondrichthyes: Mobulidae) in southeastern Brazil. Ichthyological Research 56:96-99.

Marshall A, Kashiwagi T, Bennett MB, Harding M, Stevens G, Kodja G, Hinojosa-Alvarez S, Galvan-Magana F. 2011. Manta birostris. In IUCN Red List of Threatened Species. Version 2011.1. Available at http://www.iucnredlist.org/apps/redlist/details/198921/0 (accessed 25 February 2014).

Marshall AD, Compagno LJV, Bennett MB. 2009. Redescription of the genus Manta with resurrection of Manta alfredi (Krefft, 1868) (Chondrichthyes; Myliobatoidei; Mobulidae). Zootaxa:1-28.

Marshall AD, Dudgeon CL, Bennett MB. 2011. Size and structure of a photographically identified population of manta rays Manta alfredi in southern Mozambique. Marine Biology 158:1111-1124.

Matear R, Chamberlain M, Sun C, Feng M. 2013. Climate change projection of the Tasman Sea from an Eddy-resolving Ocean Model. Journal of Geophysical Research: Oceans 118:2961-2976.

Oke PR, Middleton JH. 2001. Nutrient enrichment off Port Stephens: the role of the East Australian Current. Continental Shelf Research 21:587-606.

Oliver E, Holbrook N. 2014. Extending our understanding of South Pacific gyre "spin-up": Modeling the East Australian Current in a future climate. Journal of Geophysical Research: Oceans 119:2788-2805.

Oliver EC, Wotherspoon SJ, Chamberlain MA, Holbrook NJ. 2014. Projected Tasman Sea extremes in sea surface temperature through the twenty-first Century. Journal of Climate 27:1980-1998.

Ridgeway K, Hill K. 2012. East Australian Current. In: Poloczanska ES, Hobday AJ, Richardson AJ, eds. A Marine Climate Change Impacts and Adaptation Report Card for Australia 2012. Available at http://www.oceanclimatechange.org.au (accessed 15 December 2014)

Ridgway K, Godfrey J. 1997. Seasonal cycle of the East Australian current. Journal of Geophysical Research: Oceans (1978-2012) 102:22921-22936.

Ridgway KR. 2007. Long-term trend and decadal variability of the southward penetration of the East Australian Current. Geophysical Research Letters 34:L13613.

Roughan M, Macdonald HS, Baird ME, Glasby TM. 2011. Modelling coastal connectivity in a Western Boundary Current: Seasonal and inter-annual variability. Deep Sea Research Part II: Topical Studies in Oceanography 58:628-644.

Roughan M, Middleton JH. 2004. On the East Australian Current: variability, encroachment, and upwelling. Journal of Geophysical Research 109:C07003. 
221 Stamation KA, Croft DB, Shaughnessy PD, Waples KA. 2007. Observations of humpback whales

222

223

224

225

226

227 (Megaptera novaeangliae) feeding during their southward migration along the coast of southeastern New South Wales, Australia: identification of a possible supplemental feeding ground. Aquatic Mammals 33:165.

Wu L, Cai W, Zhang L, Nakamura H, Timmermann A, Joyce T, McPhaden MJ, Alexander M, Qiu B, Visbeck M. 2012. Enhanced warming over the global subtropical western boundary currents. Nature Climate Change 2:161-166. 
1

Map of south east Australia and sighting locations

Fig. 1. Map of south east Australia showing location of sighting of specimen \#1 (Montague Island) and specimen \#2 (north east Tasmania) $\square$ 


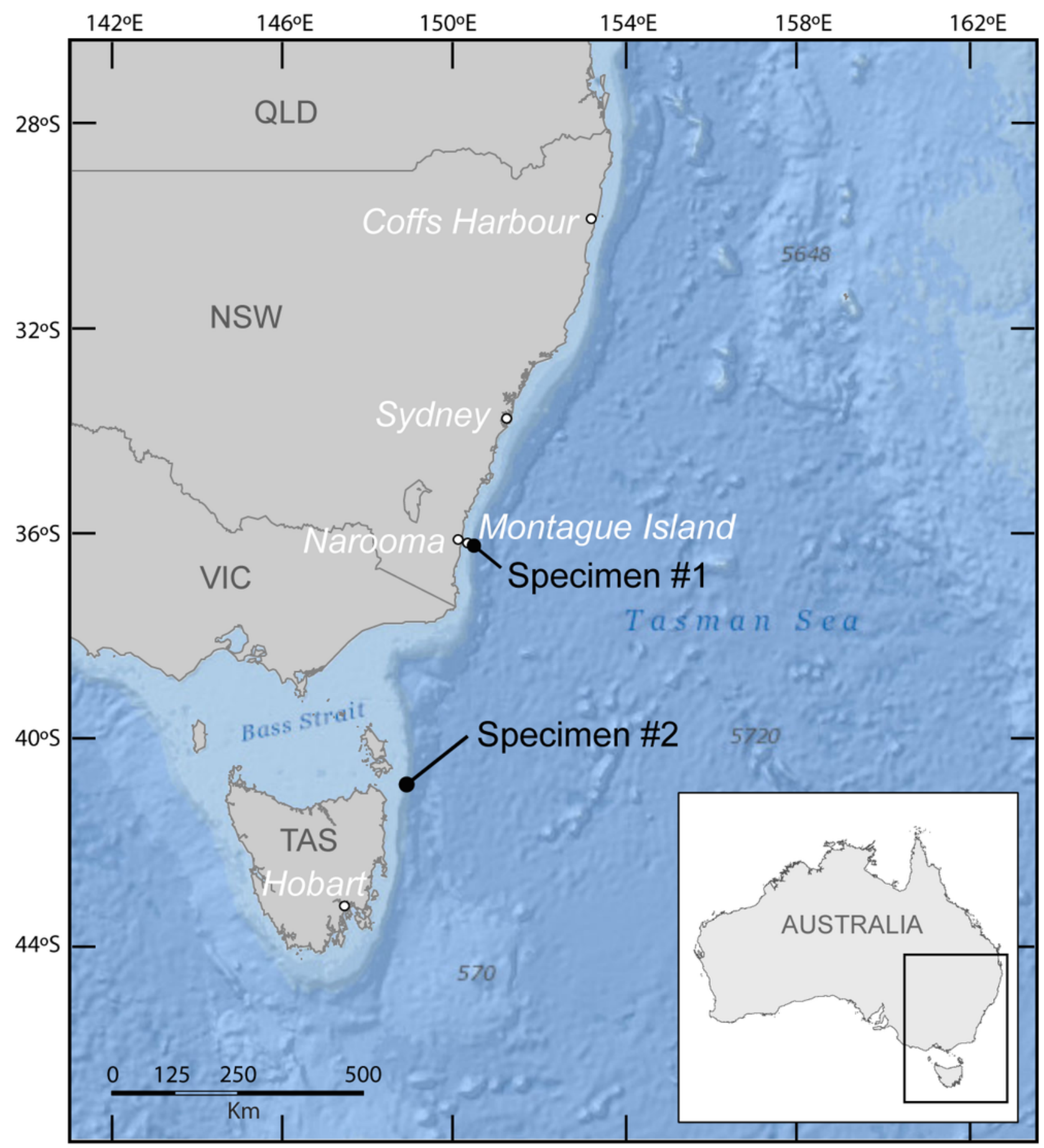


2

Photographs of a Manta birostris off Montague Island

Fig. 2. Photographs of a Manta birostris (specimen \#1) taken at Montague Island on the $5^{\text {th }}$ January 2012 by Peter McGee. White arrows indicate key characters for M. birostris as described in Marshall et al. (2009): (a) and (b) show distinctive dorsal coloration with white shoulder patches with their anterior margins extending medially from spiracles in an approximately straight line parallel to the edge of the mouth; (c) and (d) show large semicircular spots posterior to the fifth gill slits and grey V-shaped margin along posterior edge of the pectoral fin; and (d) shows dark coloration around mouth and the caudal spine, embedded in a calcified mass and covered with a skin layer immediately posterior to the dorsal fin (white box) 


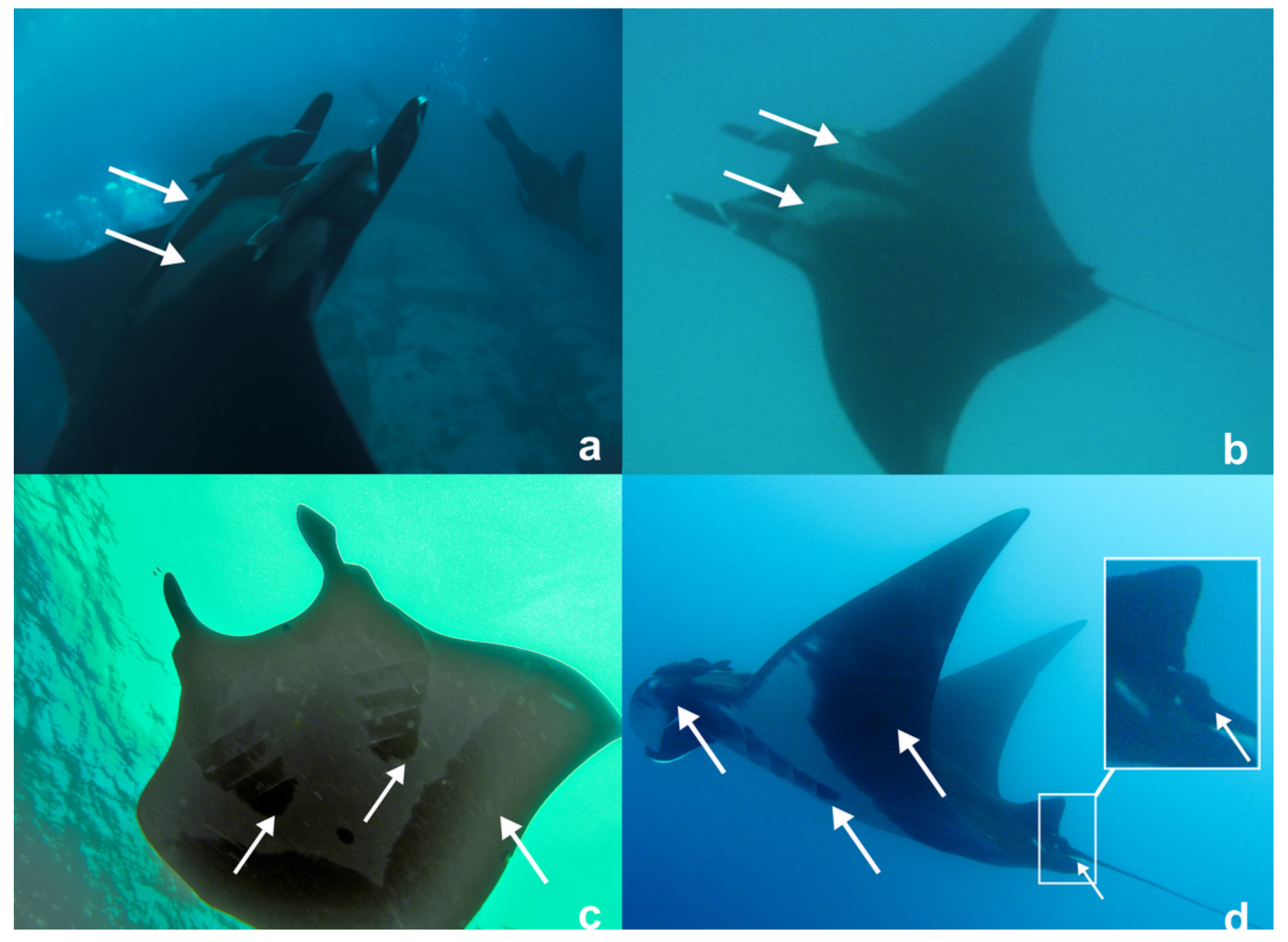


3

Photograph of Manta birostris off north east Tasmania

Fig. 3. Photographs of a Manta birostris (specimen \#2) taken off the north east coast of Tasmania on the $26^{\text {th }}$ January 2014 by Leo Miller. White arrows indicate distinctive dorsal white shoulder patches with their anterior margins extending medially from spiracles in an approximately straight line parallel to the edge of the mouth, as key character of the dorsal colouration of M. birostris as described in Marshall et al. (2009)

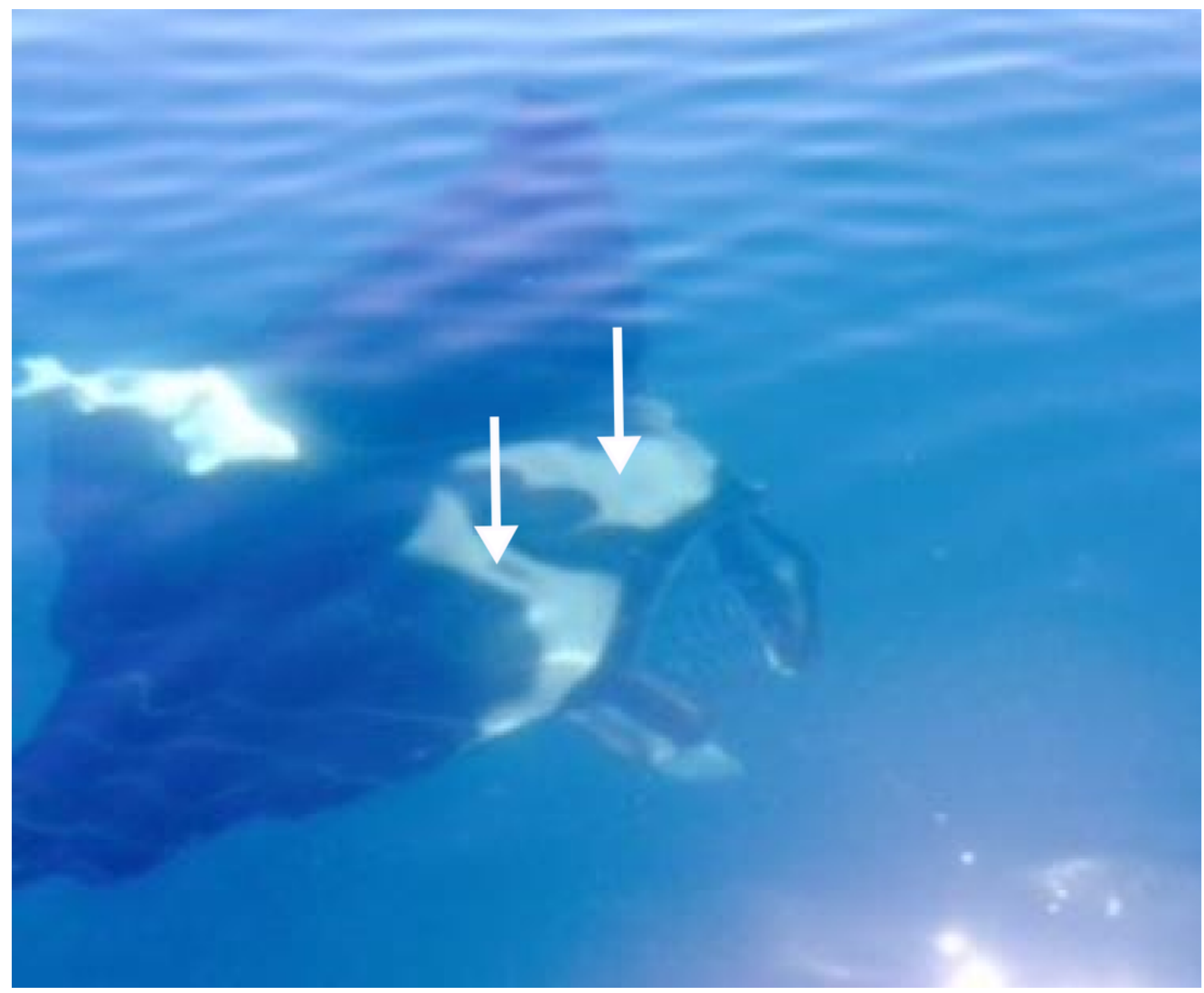

